\title{
Laboratory Methods Used for Early Diagnosis in Bitch Mastitis
}

\author{
Iosif VASIU ${ }^{1}$, Marina SPÎNU ${ }^{1}$, Mihaela NICULAE ${ }^{1}$, Raul AlexandruPOP ${ }^{2}$, Iulia BALACI ${ }^{2}$, \\ Florinel Gheorghe BRUDAŞC $\breve{A}^{1}$ \\ ${ }^{1}$ University of Agricultural Sciences and Veterinary Medicine, Faculty of Veterinary Medicine, \\ Department of Infectious Diseases, Calea Mănăştur, Nr. 3-5, 400372, Cluj-Napoca, Romania \\ ${ }^{2}$ University of Agricultural Sciences and Veterinary Medicine, Faculty of Veterinary Medicine, \\ Department of Gynecology and Obstetrics, Calea Mănăştur, Nr. 3-5, 400372, Cluj-Napoca, Romania. \\ Corresponding author: iosifvasiu@yahoo.com
}

Bulletin UASVM Veterinary Medicine 72(1) / 2015,

Print ISSN 1843-5270; Electronic ISSN 1843-5378

DOI:10.15835/buasvmcn-vm: 11026

\begin{abstract}
The aim of this paper is to review the existing literature regarding the current methods used to diagnose bitch mastitis. Compared to the information available on ruminant mammary gland inflammation, the data regarding bitch mastitis is limited.

So far microbiology assays are most widely used to identify, (based on antibiograms) and to treat mammary gland infections. Milk cytology has also been taken into consideration as a diagnostic tool. Clinicians have also started to use haematology, biochemistry and $\mathrm{pH}$ assays to confirm clinical signs of mastitis.

It is well known that one of the causes of neonatal mortality is undiagnosed episodes of mastitis. Early diagnosing of subclinical cases of glandular tissue inflammation and avoiding chronic episodes of infection, can limit neonatal mortality.
\end{abstract}

Keywords: bitch, cytology, mastitis, microbiology, milk.

\section{INTRODUCTION}

Mastitis represents the inflammation of the mammary gland tissue (Tudor, 2004; Boden, 2005). Usually, mastitis is a disease of bacterial etiology (Orfanou et al., 2008), but parasitical etiology has also been reported (Park et al. 2007).In human medicine there are reports of sarcoidosis, histoplasmosis and aspergillosis mastitis episodes (Gansler and Wheeler, 1984; Houn and Granger, 1991; Govindarajan et al. 1993; Pinto and Mandreker, 1996).

In most cases, the infection appears in the postpartum period, but it can also occur in the lactating nursing bitch, even in Lactacio sine graviditate scenarios (Merk Veterinary Manual, 2010). Mastitis can affect one or more sections of the glandular tissue or one or more mammary glands. Mammary infections can be acute and life threatening (Johnston et al., 2001). The females display general symptoms (i.e. vomiting, dehydration, anorexia, fever, trembling, decreased mothering) as well as local signs of illness (i.e. discolored milk, erythema, oedema, hardening and pain of the affected glandular tissues). There are also reported cases were the dams show no signs of illness, but the offsprings failed to thrive (Johnston et al., 2001; Wiebe and Howed, 2009; Merk Veterinary Manual, 2010; Lopate, 2012, Casal 2014in press).

When dealing with mammary gland infections, the diagnostic is usually limited toclinical examination. Milk microbiology (Jung et al., 2002), cytology (Olson and Olson, 1984) and pH test (Hasegawa et al., 1993) have also been used, not only to confirm clinical episodes of mastitis, but also to identify subclinic or chronic cases.

There are few reports in the literature were hematology and biochemistry assays have 
been taken into consideration when diagnosing mammary gland infections (Hasegawa et al., 1993; Ververidis et al., 2007).

Given the fact that bitch mastitis is commonly overlooked, early diagnosis of subclinical mastitis episodes by establishing a clear pathway to identify mammary gland inflammation, can significantly help to reduce neonatal mortality.

The aim of this review is to show practitioners worldwide the necessity of correctly diagnosing mammary gland infections in dams, whereas indiscriminate use of antibiotics may create resistant bacterial strains, in both bitch and pups.

\section{Milk microbiology}

For microbiology assays, milk is usually collected by manual expression (first milk drop being discarded) into sterile vials (Martínet al., 2010), sterile swabs with transport medium (Milani et al., 2012) or even directly on to sterilised bacteriological loops (Ververidis et al., 2007). Even the fine needle aspirate technique has been used (Sangha et al., 2011).

Standard microbiology techniques for isolation and identification of bacteria are currently used. A loop full of mammary secretion is plated onto blood agar, (especially for isolation of Stahpylococcus and Streptococcus spp.) and McConkey (selective for some Enterobacteriaceae), beeing incubated for $24-72 \mathrm{~h}$ at $37^{\circ} \mathrm{C}$ in aerobic and modified atmosphere $\left(\begin{array}{lll}5 \% & \mathrm{CO}_{2}\end{array}\right)$ conditions (SchäferSomi, 2003). Initial identification of bacteria is performed by macroscopic observation of colonies, Gram stain, cellular morphology, oxidase, catalase, mobility and oxidation-fermentation tests, type of haemolysis for Streptococcus spp., and coagulase for Staphylococcus spp. (Milani et al., 2012). Biochemical incorporated API systems commercial tests are used to identify bacterial species (Schäfer-Somi, 2003). Additionally, after two days enrichment in Thioglycollate medium fluid and Trypticase Soy broth, cultural procedures on solid media are performed (Schäfer-Somi, 2003).

For lactobacilli isolation, milk samples are diluted in peptone water, then plated onto Man. Rogosa and Sharpe agar plates and then aerobically incubated at $37^{\circ} \mathrm{C}$ for $24 \mathrm{~h}$. The same samples are cultured on MRS supplemented with L-Cysteine $(0.5 \mathrm{~g} / \mathrm{L})$, (MRS-Cys) agar plates, anaerobically (85\% nitrogen, $10 \%$ hydrogen, $5 \%$ carbon dioxide) at $37^{\circ} \mathrm{C}$ for $48 \mathrm{~h}$ (Martín et al., 2010).
Staphylococcus pseudintermedius and Streptococcus canis are very important pathogens in dogs and cats (Weese, 2008). Results of microbiology assays show a relatively wide spectrum of bacteria isolates. So far, from bitches with mastitis acuta, haemolyticStaphylococcus spp., Staph. intermedius, Staph. haemolyticus, $\beta$ haem. Streptococcus, Klebsiella pneumoniae, E. coli and Proteus miriabilis have been identified (Schäfer-Somi, 2003).

From asymptomatic females, Staph. intermedius, haem. Staphylococcus spp., Staph. epidermitis, Staph. simulans, $\beta$ haem. Streptococcus, E. coli, Enteroccocus durans, P. stuterzi, Shighella spp., Acinetobacter anitratusand Bacillus spp. have been isolated (Schäfer-Somi, 2003). Jung et al.(2002) also isolated $\alpha$-hemolytic Streptococci and $\gamma$-haemolytic Streptococci.

Araújoet al., (2011) proved that Staph. hyicus can produce mammary gland inflammation accompanied by lymphadenitis, by isolating the pathogen from a three-year-old Pitt bull female, which died after amastitis acuta episode (Araújo et al., 2011). There is also one experimental bitch mammary gland infection with a Staph. intermedius strain in six primiparous Beagle-breed females (Ververidis et al., 2007).

Martín et al., (2010) managed to isolate lactobacilli ( $L$. murinus, L. animalis, L. reuteri, $L$. johnsonii and L. fermentum) and E. faecium, E. faecalis, Strept. salivarius, Staph.epidermidis, Strept. bovis, Staph. simulans, Staph. pseudintermedius, $W$. viridescens and yeast from bitch milk.

However, enterococci can be opportunistic pathogens and may cause a range of different infections in animals and humans, including mastitis. E. faecalis and E. faecium strains isolats, constitue a pathogenic reservoir for offsprings (Jiménez et al., 2013).

It has also been suggested that bacteria isolated from the mammary gland and vagina, are responsible for neonatal infections (Sager and Remmers, 1990; Münich and Lübke, 2004). In order to eliminate bacterial flora and hopefully, to eliminate the neonatal mortality risk, many dog breeders treat dams before and after parturition with antibiotics.Unfortunately, this practice will only predispose the vagina to colonisation by opportunistic pathogens and will select resistant bacteria strains (De Graef et al., 2004; Rota et al. 2011). 
Because milk is acidic, weak base antibiotics distributes and gets trapped into it. Macrolids, amoxicillin-calvulanated or cephalexin may be empirically initiated until culture results return (Martí, 2009).

\section{Milk biophysical parameters}

Due to the limited amount of milk acquired from dams, milk $\mathrm{pH}$ values are recorded by using litmus paper (Dziecioł et al., 2006). Parameters such as clorhide levels have also been measured (Hasegawa et al., 1993; Dziecioł et al., 2006).

Milk pH values obtained so far (Hasegawa etal., 1993, Dziecioł et al., 2006) suggests that females suffering from mastitisacuta have an alkaline $\mathrm{pH}$ value of 7, whilst females diagnosed with Lactatio sine graviditate have a more basic $\mathrm{pH}$ value (i.e. 6.7). Tests have shown that healthy dams have a more acid $\mathrm{pH}$ level of about 6.3 averages.

Chloride levels registered show an increase in (mean=199mg \%) cases of mastitis. Healthy females and females with Lactatio sine graviditate have been found to have similar results, $84.3 \mathrm{mg} \%$, respectively $84.1 \mathrm{mg} \%$ (Dziecioł et al., 2006).

\section{Milk cytology}

Milk cytology is carried out by using secretion films made by the direct smearing squash technique (Meyer et al., 2010) using about $20 \mu \mathrm{l}$ of each collected sample on microscope objective plate.

The squash technique is an adaptable procedure for management of semisolid, mucuslike or pelleted by centrifugation cytology specimens. A small amount of material is placed on a clean glass slide, approximately $1 \mathrm{~cm}(1 / 2$ inch) from the frosted end. A second clean slide is placed over the specimen at right angles. The specimen is gently but firmly compressed between the two glass slides and in the same continuous motion the top slide is pulled along the surface of the bottom slide, directing the material away from the frosted end. The objective is to redistribute the material, turning a multicellular mass into a thin monolayer ideal for maximal flattening of individual cells and even stain penetration. The compression preparation thus optimizes the specimen for microscopic examination of cell morphology. A properly prepared glass slide is characterized by a feather-shaped area with a monolayer end referred toas the "sweet spot", (Sabău and Rotaru, 2006a; Meyer et al., 2010).
Smears are stained by using the Giemsa (Ververidis et al., 2007), Wright-Giemsa (Olson and Olson, 1984) or Wright-Leishman (Sangha et al., 2011) technique. Romanowsky-type stains are preferred because they work rapidly and are easy to use (Sabău and Rotaru, 2006a; Meyer et al., 2010). For diagnostic, in ruminant mastitis, the May-GrunwaldGiemsa stain technique is the most used amongst the Romanowsky-type stains (Sabău and Rotaru, 2006b).

The percentage of leukocyte subpopulation is determined by distinguishing types of inflammatory cells within the films (Ververidis et al., 2007). For total cell counts, Olson and Olson, (1984) use a white blood cell (Unopette - BectonDickinson) andhemacytometer counting chamber, whereas $20 \mu \mathrm{l}$ of milk is placed in Unopette diluent. To aid differentiating inflammatory milk cells from fat droplets, $20 \mu \mathrm{l}$ of Diff-Quick solution II is added. Total cell counts of milk samples are expressed as cells/ $\mu$ l of milk (Olson and Olson, 1984). The Whiteside test has also been used to confirm clinical mastitis (Ververidis et al. 2007).

Few studies have looked into bitch milk cytology. There is one study carried out in 1984 that evaluates canine milk cytology (Olson and Olson, 1984). This study shows cytology variations among glands from the same dam. In canine milk, macrophages and polymorphonuclear leukocytes are common isolates. Macrophages with ingested milk fat vary greatly in size. Even in milk of healthy bitches, polymorphonuclear leukocytes present pyknotic nuclei. Severely degenerated neutrophils with engulfed bacteria are seen in milk collected from females that suffer from septic mastitis (Olson and Olson, 1984).

Plasma cells, lymphocytes, cells with degenerated nuclei and round nuclei are also present. In milk samples collected from bitches resorbing milk, fewer fat droplets are present than in samples collected from milking females (Olson and Olson, 1984). Bacteria from healthy dams, resulting from skin contaminants are present in milk samples, unless bacteria are accompanied by increased cell counts and phagocytosis, proof of mammary gland infection (Olson and Olson, 1984). Galactostasis cases are accompanied by an increased count of eosinophils. Engulfed blood pigment or erythrocytes are evidence of milk blood traces (Olson, 1984). 
Milkinflammatory cell response (macrophagic foamy cells, neutrophils and eosinophils) have been also reported in a 6-year-old Bernese female dog living in Italy, presenting with a breast lump. Cytology examination of the nipple secretion fluid smears showed the presence of glandular cell clusters and of some nematodes (Dirofilariarepens) of about $350 \mu \mathrm{m}$ in length in the background (Manuali et al., 2004).

There are reports in human medicine of breast inflammatory lesions with various causes, including actinomycosis in acute, subacute mastitis and abscess. As a response to the injury, numerous polymorphonuclear leukocytes, scattered ductal cells and necrotic material are found on smears (Koss and Melamed, 2006).In chronic cases, especially in developing countries, breast tuberculosis lesions, such as columnar, oddly shaped and multinucleated giant cells surrounded by inflammatory infiltrate, have been reported (Shinde et al., 1995).

Some authors (Fontaine et al., 2007) suggest that bitch milk cytology has no clinical importance. Sanghaet al. (2011) proved that milk cell counts increase during bitch mastitis episodes by comparing cytological findings with histological diagnose. A 70\% concordance had been found by correlating these assays (Shanga et al., 2011).

Dziecioł et al. (2006), during their research, found an increased somatic cell count in bitch milk. Two weeks from delivery, mean somatic cell count were $<3 \times 10^{6} \mathrm{ml}^{-1}$. Between 3-5 weeks after delivery, mean values were about $<3,8 \times 10^{6} \mathrm{ml}^{-1}$ and 6-8 weeks after delivery mean values were about $<4,9 \times 10^{6} \mathrm{ml}^{-1}$ (Dziecioł et al, 2006).

In vivo experiments (Ververidis et al., 2007) showed an increased somatic cell count at $12 \mathrm{~h}$ after inoculation of Staph. intermedius in the right caudal abdominal mammary gland of six Beagle females, and remained high through lactation. In samples taken from control glands, the values also increased $12 \mathrm{~h}$ after inoculation but did not remain high during lactation (Ververidis et al., 2007).

In the examined secretion films, neutrophils predominate $(>75 \%)$ in initial stages. During the $11^{\text {th }}$ day post challenge, the proportion began to reduce. From the $3^{\text {rd }}$ day post challenge, degenerated neutrophils were already evident. Lymphocytes were also present $(20 \%)$ after the $6^{\text {th }}$ day of challenge and began to predominate from day 14. Similar findings were seen in the control glands. However, macrophages and lymphocytes were found in a high proportion ( $>25 \%)$, but in fewer numbers in later stages (Ververidis et al., 2007).

Cytology should be interpreted with caution as it is normal for low numbers of neutrophils and eosinophilsto be present in healthy bitch milk. However, large numbers of neutrophils and presence of engulfed bacteria is consistent with infections (Olson and Olson, 1984). Keeping in mind the indiscriminate use of antibiotics, treatment should at least be based first on cytological examination of milk secretion (Lopate, 2012).

\section{Blood test}

For hematology and biochemical assays, blood is harvested from the jugular vein into heparin- or EDTA-containing vials. Standard full hematological tests are carried out by using bloodanalyzer. Albumin, total serum proteins, globulins (Hasegawa et al., 1993; Ververidis et al., 2007) and haptoglobin measurement (Dziecioł et al., 2006), are carried out using biochemical analyzers (Ververidis et al., 2007).

To the author's knowledge, there is only one documented case (Hasegawa et al., 1992) of mastitis gangrenosa in bitch, were biochemical and hematological changes had been recorded (Hasegawa et al., 1992).

Laboratory findings showed marked leukocytosis $(36,300 / \mu \mathrm{l})$, marked increased of $\alpha$, $\beta$ and $\gamma$-globulines, mild anemia, slight increase of plasma alkaline phosphatase and creatine phosphokinase levels, mild hypernatremia and hypokalemia on the day of admission. Additionally, large platelets were observed in the blood smears. The number of circulating leukocytes, temporarily decreased $(26,000 / \mu \mathrm{l})$ on day 1 . Increased peripheral leukocytes $(48.600 / \mu \mathrm{l})$, decreased circulating platelets $(179,000 / \mu \mathrm{l})$, abnormal pattern of platelets and bad physical condition were recorded on the same day (Hasegawa et al., 1992).

Experimental infection (Ververidis et al., 2007) shows a significant overall increase of leukocyte counts after challenge. Nevertheless, after $12 \mathrm{~h}$, there was a decrease of leukocyte counts, followed by a sharp increase. Leukocyte counts had returned to pre-challenge values after the $6^{\text {th }}$ day. After challenge, the neutrophil counts had significantly increased. Total neutrophil 
count returned to pre-challenge values after day 6. Twelve hours after challenge, there was a significant platelet count decrease, followed by an increase during the fourth day.

There were no significant changes in the globulin, albumin and haematocrit values during this experiment (Ververidis et al., 2007).

Some author`s (Lopate, 2012) signaled that in cases of mastitis, leukocytosis, with or without a degenerative left shift, eosinophilia, dehydration, increased renal and hepatic enzymes and electrolyte abnormalities may be found (Lopate, 2012).

\section{Acute-phase proteins}

In recent years, in veterinary medicine, Acute-phase proteins (APPs), such as Haptoglobin (Hp), serum amyloid A (SAA), C-reactive protein (CRP), $\alpha_{1}$-acid glycoprotein (AGP), fibirinogen (Fb) and albumin (Eckersall, 1995) had started to be used to diagnose and assess inflammatory processes (Ceron et al., 2005). These proteins are also used to evaluate the evolution of selected diseases (Kocaturk et al., 2010). This review aims to highlight the use of Haptoglobin as a potential marker for bitch mammary gland infections, by comparing the available data for bitch and cow mastitis.

The acute phase response is stimulated by the release of cytokines such as interleukin-1 (IL1), interleukin-6 (IL-6) and tumor necrosis factor $\alpha(\mathrm{TNF} \alpha)$. Inflammatory lesions or infections stimulate macrophages and monocytes to release this cytokines (Eckersall, 2000).

The acute phase proteins are synthesized by hepatocytes upon stimulation of the proinflammatory cytokines, released into the blood stream (Gruys et al., 1994; Eckersall, 2000; Ceron et al., 2005).

In dogs, APPs are used to diagnose and assess the health status of individuals suffering from various diseases (Eckersall, 2000; McGrotty et.al, 2003; Maier et al., 2004; Ulutaş et al., 2007). Lately, these proteins are used to assess the health status of breeding bitches as well. Changes in APPs (serum amyloid A, C-reactive protein, haptoglobin, ceruloplasmin and fibrinogen) produced in response to ovariohysterectomy in healthy bitches and those with pyometra, including APPs levels in pregnancy and oestrus cycles have been assessed (Dąbrowski et al., 2007; Ulutaş et al., 2009; Serin and Ulutaş, 2010; Dąbrowski et al., 2013).
Dziecioł et al., (2006) focused their research on Hp levels in lactating bitches. The level of $\mathrm{Hp}$ indicating inflammation ranged between 4-9 mg/ $\mathrm{ml}$ (Dziecioł et al., 2006). Haptoglobin increase is strictly correlated with the degree of tissue damage. This particular APP reaches the maximum concentration, after tissue damage in 3-5 days (Kostro et al., 1996; Cerón et al., 2005).

Haptoglobin concentration reflects the intensity of inflammatory processes irrespective of the site of blood collection (Dąbrowski et al., 2013). C-reactive protein and serum amyloid A react rapidly, whilst Hp reacts slowly (Dąbrowski et al., 2009). Haptoglobin in dogs is considered to be a moderate APP, as it increases 2-3-fold in response to infection, trauma or inflammation (Eckersall 1995; Eckersall and Conner, 1998).

In dogs, normal $\mathrm{Hp}$ plasma levels range between 0-1.69 $\mathrm{mg} / \mathrm{L}$. In dogs diagnosed with polyarthritis mean Hp level registered were 11.6 $\mathrm{mg} / \mathrm{ml}$, with a range of 7.2-16.5 $\mathrm{mg} / \mathrm{ml}$ (Eckersall et al., 1999).

In females suffering from mastitis acuta, the Hp recorded levels ranged between 5.3-7.5 mg/ $\mathrm{ml}$. In mastitis cronica, the recorded levels ranged between 2.2 and $2.5 \mathrm{mg} / \mathrm{ml}$. In bitches diagnosed with lactatio sine graviditate, the obtained value did not exceed $0.6 \mathrm{mg} / \mathrm{ml}$ (i.e. 9 females), (Dziecioł et al., 2006). Usually, in dogs, $24 \mathrm{~h}$ after surgical trauma, the Hp level increases 2-5 fold (Cerón et al., 2005).

In ruminants, $\mathrm{Hp}$ is a valuable marker of disease. It is considered as a major APP (Eckersall et al., 1999; Eckersall, 2000). In cows, the normal Hp level ranges between 22-47 mg/L. Experimental $E$. coli mastitis infection in cows, showed a significant Hp level increase (i.e. 52-fold). Furthermore, 12 hours after challenge, the haptoglobin value already started to increase, whilst the highest $\mathrm{Hp}$ levels were recorded between 48-120 hours after challenge (Salonen et al., 1996).

Other experimental infections in cows, recorded no $\mathrm{Hp}$ value before bacterial challenge. The maximum obtained value was reached 2-3 days post-challenge. Haptoglobin levels have predictive accuracy as well (Hirvonen et al., 1996). However, serum Hp does not always correlate with severity of disease and could not discriminate the fatal E. coli cases (Hirvonenet al., 1999).

Furthermore, rapid increase of milk somatic cells after repeated challenges indicates that milk 
inflammatory cells are primed by previous $E$. coli challenge. Subsequent Hp challenges do not increase at the same level as in the first challenge scenarios (Salonenetal., 1996).

In subclinical infections, the pro-inflammatory cytokines increase. Henceforth, APPs levels are used in slaughterhouses as indicators of food safety. Mean Hp herd levels are also related to the hygiene level of the production facilities (Eurell et al., 1992; Kostro et al., 1996; Petersen et al., 2003). Haptoglobin level is also used in swine husbandry, as a biomarker for weight gain (Eurell et al., 1992).

\section{CONCLUSIONS}

Because bitch mammary infections are widely overlooked, extra care should be taken into evaluating post-partum pathology. Bacterial pathogens that cause mammary infections can migrate from the uterus and vagina to the mammary glands (haematogenous transmission), (Fontaine et al., 2007).

Graham and Taylor (2012) suggest that exogenous infections of the mammary glands are rare and commonly infections of the reproductive tract are of endogenous origin. Many of the bacterial pathogens involved in the reproductive tract are part of the urogenital microflora. Therefore bacterial infections (i.e. bacteriemia and endotoxiemia) are opportunistic and predisposing factors must be present for the disease to develop, thus establishing a definitive diagnosis can be challenging (Graham and Taylor, 2012).

Bacteria strains from skin and oral mucosa of both, the dam and the offspring, can be responsible for mammary gland infections (exogenous transmission), especially in Lactatio sine graviditate scenarios, where the bitch frequently licks the mammary glands (Jung et al., 2002).

There are also reports were the same bacterial strains had been isolated from bitch milk and puppies diagnosed with septicaemia (Münnich and Lübke, 2004; Rota et al., 2011). Conditions such as pyometra, metritis or puerperal vaginitis can predispose the nursing dams to glandular tissue inflammation, predisposing the litter to septicaemia, neonatal mortality or "fading puppy syndrome" (Schäfer-Somi et al., 2003, Milani et al., 2012).

Endotoxemia is also a potentially fatal sequel to mastitis (Graham and Taylor, 2012). Reports of neonatal septicemia caused by a Streptococcus dysgalatiaesubs. dysgalactiae strain isolated from two dead puppies have also been related (Vela et al., 2006).

Mastitis gangrenosa has also been signaled in cats (Wilson, 2013). Furthermore, there are reports in the literature were fibroadenomatous hyperplasia in cats complicate with mammary abscess (Burstyn, 2010) highlighting the important role of mammary gland infection management.

Milk samples should be obtained for cytology and microbial culture and susceptibility tested before antibiotic therapy is initiated (Casal, 2014, in press). Early diagnosis of a subclinical mammary infection can help prevent postpartum complications (i.e. mortality in pups, antibiotic resistance). Avoiding prophylactic administration of antibiotics is one of the major advantages of early diagnosing mastitis episodes.

In mammary cancer, the prognosis is guarded to poor (Rutteman and Kirpensteijn, 2003), whilst in mastitis, except for gangrenous cases, the prognosis is usually good. Given the circumstances, it is of the uttermost important to differentiate between a mammary inflammatory response and mammary neoplasia, both in human and veterinary medicine. By correctly interpreting mammary or milk cytology, a correct diagnosis and differentiation can be made between the two mentioned morbid entities.

Because dogs and people live in close contact, risk of bacteria transfer from one to the other is high (Wedley et al., 2011). Transfer of milk pathogens from humans to bitch milk is therefore possible. Extra care should be provided when handling puppies and the bitch`s mammary glands by owners and veterinary staff.

Laboratory test (i.e. pH, cytology, biochemistry, hematology, microbiology) should become the golden standard when veterinary specialists start to manage mammary gland infections. In cows, when milk samples are not available, Hp is used as a mastitis indicator (Eckersallet al., 1999). In order to early diagnose a bitch mammary gland infection, further research is required to precisely establish which parameters better suits for a clear diagnostic.

Acknowledgements. The warmest of thanks to TressaRebek-Nagy for helping with English grammar and spelling. 


\section{REFERENCES}

1. Araújo RM, Preis SI, França AS, Paniago GJ, Costa CM, Oliveira SVJ, Ecco R (2011). Mastitis accompanied by lymphadenitis in a dog caused by Staphylococcus hyicus. Braz J Vet Pathol 4:52-57.

2. Boden E (2005). Black`s Veterinary Dictionary. $21^{\text {st }}$ ed. A\&C Black, London, UK.

3. Burstyn U (2010). Management of mastitis and abscessation of mammary glands secondary to fibroadenomatous hyperplasia in a primiparturient cat. J Am Vet Med Assoc 236:326-329.

4. Casal LM (2014inpress). Mastitis, p. 527-530. In: Silverstein C. Deborah and Hopper Kate (Ed.). Small animal critical care medicine. Second Edition, Elsevier Saunders.

5. Cerón JJ, Eckersall PD, Martínez-Subiela S (2005). Acute phase proteins in dogs and cats: current knowledge and future perspectives. Vet ClinPathol 34:85-99.

6. Cortney RW (2013). Feline gangrenous mastitis. Can Vet J 54(3):292-294.

7. Dabrowski R, Kosto K, Szczubiał M (2013). Concetrations of C-reactive protein, serum amyloid A and haptoglobin in uterine arterial and peripheral blood in bitches with pyometra. Theriogenology 80:494-497.

8. Dąbrowski R, Kostro K, Lisiecka U, Szczubial M, Krakowski L (2009). Usefulness of C-reactive protein, serum amyloid A component and haptoglobin determinations in bitches with pyometra for monitoring early postovariohysterectomy complications. Theriogenology 72:471-476.

9. Dąbrowski R, Wawron W, Kostro K (2007). Changes in CRP, SAA and haptoglobin produced in response to ovariohysterectomy in healthy bitches and those with pyometra. Theriogenology 67:321-327.

10. De Graef EM., Decostere A, Devriese LA, Haesebrouck F (2004). Antibiotic resistance among fecal indicator bacteria from healthy individually owned and kennel dogs. Microb Drug Resist 10:65-9.

11. Dziecioł M, Stefaniak T, Twardon J, Kozdrowski R (2006). Wybranewskanikimleka i krwisukzezdrowym i chorymgruczolemsutkowym, [Chosen parameters of the milk and blood of bitches with healthy mammary glands and those suffering from mastitis]. Med Weter 62:59-61.

12. Eckersall PD (1995). Acute phase proteins as markers of inflammatory lesions. Comp Haematol Int 5:93-97.

13. Eckersall PD, Conner JG (1988). Bovine and canine acute phase proteins. Vet Res Commun 12:169-178.

14. Eckersall PD, Duthie S, Safi S, Moffatt D, Horadagoda NU, Doyle S, Parton R, Bennett D, Fitzpatrcik JL (1999). An automated biochemical assay for haptoglobin: prevention of interference from albumin. Comp Haematol Int 9:117124.

15. Eckersall PD (2000). Recent advances and future prospects for the use of acute phase proteins as markers of disease in animals. Revue Méd Vét 151(7)577:584.

16. Eurell TR, Bane DP, Hall WF, Schaeffer DJ (1992). Serum Haptoglobin concentration as an indicator of weight gain in pigs. Can J Vet Res 56:6-9.

17. Fontaine E, Tanneur ML, Josien A (2007). Mammitegangreneuse chez la chiennereproductrice. Le Point Vétérinaire 276:25-29.
18. Gansler TS, Wheeler JE (1984). Mammary sacoidosis. Two caseds and literature review. Arch Pathol Lab Med 108:637-675.

19. Govindarajan M, Verghese S, Kuruvilla S (1993). Primary aspergillosis of the breast. Report of a case with fine needle aspiration cytology diagnosis. ActaCytol 37:234236.

20. Graham EM, Taylor DJ (2012). Bacterial reproductive pathogens of cats and dogs. Vet Clin Small Anim 42:561:582.

21. Gruys E, Oblovo MJ, Toussaint MJM (1994). Diagnostic significance of major acute phase proteins in veterinary clinical chemistry: a review. Ve Bul 64:1009-1018.

22. Hasegawa T, Fuji M, Fukada T, Tduji C, Fujita T, Goto Y, Shinjo T, Ogawa H (1993). Platelet abnormalities in a dog suffering from gangrenous mastitis by Staphylococcus aureus infection. J Vet Med Sci 55:169-171.

23. Hirvonen J, Eklund K, Teppo AM, Huszenicza G, Kulcsar M, Saloniemi H, Pyörälä S (1999). Acute phase response in dairy cows with experimentally induced Escherichia coli mastitis. Acta Vet Scand 40:35-46.

24. Hirvonen J, Pyörälä S, Jousimies-Somer H (1996). Acute phase response in heifers with experimentally induced mastitis. J Dairy Res 63:351-360.

25. Houn HY, Granger JK (1991). Granulomatous mastitis secondary to histoplasmosis: report of a case diagnosed by fine-needle aspiration biopsy. DiagnCytopathol 7:281285.

26. Jiménez E, Ladero V, Chico I, Madonado-Barragán A, López M, Martín V, Fernández L, Fernández M, Álvarez MA, Torres C, Rodriguez M (2013). Antibiotic resistance, virulence determinants and production of biogenic amines among enterococci from ovine, feline, canine, porcine and human milk. BMC Microbiol 13:288.

27. Johnston DS, Root Kustritz MV, Olson Patricia NS (2001). Periparturient Disorders in the Bitch, p.129-145. In: Johnston DS, Root Kustritz MV, Olson Patricia NS (Eds.). Canine and feline theriogenology. W.B. Saunders Company, Philadelphia, Pensylvania.

28. Jung C, Wehrend A, König A, Bostedt H (2002) Untersuchung $\mathrm{zu}$ vorkommen, differenzierung und erregerspektrum caniner mastitiden, [Investigations about the incidence, differentiation and microbiology of canine mastitis]. Prakt. Tierarzt 83:508-511.

29. Kocaturk M, Martinez S, Eralp 0, Tvarijonaviciute A, Ceron J, Yilmaz Z (2010). Prognostic value of serum acutephase proteins in dogs with parvoviral enteritis. J Small AnimPract 51:478-483.

30. Koss LG, Melamed MR (2006). 29 - The breast, p. 10821147. In: Koss L. G. and M. R. Melamed (Ed.).Diagnostic cytology and its histopatologic base, $5^{\text {th }}$ Ed. Lippincott Willians\& Wilkins.

31. Kostro K, Sobieska M, Wiktotowicz K, Wołoszyn S (1996). Białkaostrejfazy u zwierząt - występowanie I charakterystyka [The acute phase proteins in animals occurrence and characteristics]. Medycyna Wet 52:3.

32. Lopate C (2012). Reproductive physiology of canine pregnancy and parturition and conditions of the periparturient period, p. 25-41. In: Lopate C (Ed.). Management of pregnant and neonatal dogs, cats and exotic pets. Wiley-Blackwell. 
33. Maier W, Altwegg LA, Corti O, Gay S, Hersberger M, Maly FE, Sütsch G, Roffi M, Neidhart M, Eberli FR, Tanner FC, Gobbi S, von Eckardstein A, Lüscher T (2005). Inflammatory markers at the site of ruptured plaque in acute myocardial infarction, locally increased interleukin- 6 and serum amyloid A but decreased C-reactive protein. Circulation 1335:1361.

34. Manuali E, Eleni C, Giovannini P, Costarelli S, Ciorba A (2004). Unusual finding in a nipple discharge of a female dog: dirofilariasis of the breast. DiagnCytopathol 32:2.

35. Martí AJ (2009). Clinical aspects of mammary disease in the bitch and queen, Proceeding of the SEVC Southern European Veterinary Conference. 2-4.

36. Martín R, Olivares M, Pérez M, Xaus J, Torre C, Fernández L, Rodríguez J (2010). Identification and evaluation of the probiotic potential of lactobacilli isolated from canine milk. Vet J 185:193-198.

37. McGrotty Y, Knottenbelt CM, Ramsey IK, Reid SWJ, Eckersall PD (2003). Haptoglobin concentrations in a canine hospital population. Vet Rec 152:562-564.

38. Meyer JD, Connolly SL, Heng HG (2010). The acquisition and management of cytology specimens, p. 1-15. In: Raskin ER and Meyer DJ. (Ed.). Canine and feline cytology, a color atlas and interpretation guide. Saunders Elsevier.

39. Milani C, Corrò M, Drigo M, Rota A (2012). Antimicrobial resistance in bacteria from breeding dogs housed in kennels with different neonatal mortality and use of antibiotics. Theriogenology 78:132-1328.

40. Münnich A, Lübke-Becker A (2004). Escherichia coli infections in newborn puppies - - clinical and epidemiological investigations. Theriogenology 62:56275.

41. Olson N Patricia, Olson AL (1984). Cytologic evaluation of canine milk. Vet Med Small Anim Cl 79:641-646.

42. Orfanou DC, Ververidis HN, Boscos CM, Fthenakis GC (2008). Post-partum pathological conditions in the bitch - Part I. J Hellenic Vet Med So 59(2):126-138.

43. Park C-H., Ikadai H, Yoshida E, Isomura H, Inukai $H$, Oyamada T (2007). Cutaneous Toxoplasmosis in a female Japanese cat. Vet Pathol 44:683.

44. Petersen HH, Nielsen JP, Heegaard PMH (2003). Application of acute phase protein measurements in veterinary clinical chemistry. Vet Res 35:163:17.

45. Pinto RG, Mandreker S (1996). Fine needle aspiration cytology of adenoma of the nipple. A case report. ActaCytol 40:789-791.

46. Rota A, Milani C, Drigo I, Drigo M, Corrò M (2011). Isolation of methicillin-resistant Staphylococcus pseudintermedius from breeding dogs. Theriogenology 75:115-21.

47. Rutterman RG, Kirpensteijn J (2003). Tumours of the mammary glands, p. 234-243. In: Dobson M Jane and Lascelles BDX (Ed.). BSAVA Manual of Canine and Feline Oncology, second edition.

48. Sabău D, Rotaru O (2006a). Obținerea preparatelor citologice, p. 118-126. In: Sabău D and Rotaru O. (Ed.) Celulele somatice şisănătatea laptelui, AcademicPres.

49. Sabău D, Rotaru O (2006b). Tehnici de colorare aplicabile în citologia laptelui, p. 126-149. In: Sabău D and Rotaru 0 (Ed.). Celulele somatice şi sănătatea laptelui, AcademicPres.
50. Sager M, Remmers C (1990). Perinatal mortality in dogs. Clinical, bacteriological and pathological studies [in German]. TierarztlPrax 18:415-9.

51. Salonen M, Hirvonen J, Pyörälä S, Sankari S Sandholm M (1996). Quantitive determination of bovine serum haptoglobin in experimentally induced Escherichia coli mastitis. Researche in Vet Sci 60:88-91.

52. Sangha S, Singh A, Sood NK, Gupta K (2010). Specificity and sensitivity of cytological techniques for rapid diagnosis of neoplastic and non-neoplastic lesions of canine mammary gland. Braz J Vet Pathol 4:13-22.

53. Schäfer-Somi S, Spergser J, Breitenfellner J, Aurich JE (2003). Bacteriological status of canine milk and septicaemia in neonatal puppies - a retrospective study. J Vet Me 50:343-346.

54. Serin G, Ulutaş PA (2010). Measurement of serum acute phase proteins to monitor postoperative recovery in anoestrous bitches after ovariohysterectomy. Vet Rec 166:20-22.

55. Shinde SR, Chandawarkar RY, Deshmukh SP (1995). Tuberculosis of the breast masquerading as carcinoma: a study of 100 patients. World J Surg 19:379-381.

56. The Merk Veterinary Manual. (2010). Reproductive diseases of the female small animal, p. 1281-1286. Merck\&Co. Inc. N.J. USA.

57. Tudor D (2004). Dicționar de medicină veterinară. ed. Vergiliu, București.

58. Ulutaş PA, Musal B, Kiral F, Bildik A (2009). Acute phase protein levels in pregnancy and oestrus cycle in bitches. Res Vet Sci 86:373-376.

59. Ulutaş PA, Ulutaş B, Sarirler M, Bayramli G. (2007). Serum haptoglobin and ceruloplasmin concentrations in dogs with various diseases. J Fac Vet Med Istanbul Univ 33(2):35-42.

60. Vela IA, Falsen E, Simarro I, Rollan E, Collins MD, Domínguez L, Fernandez-Garayzabal JF (2006). Neonatal mortality in puppies due to bacteriemia by Streptococcus dysgalatiae subsp. dysgalactiae. J ClinMicrob 44(2):666669.

61. Ververidis HN, Mavrogianni VS, Fragkou IA, Orfanou DC, Gougoulis DA, Tzivara A, Gouletsou PG, Athanasiou L, Boscos CM, Fthenakis GC (2007). Experimental Staphylococcal mastitis in bitches: Clinical, bacteriological, cytological, haematological, and pathological features. Vet Microbiol 124:95-106.

62. Wedley AL, Maddox TW, Westgarth C, Coyne KP, Pinchbeck GL, Williams NJ, Dawson S (2011). Prevalence of antimicrobial-resistant Escherichia coli in dogs in a cross-sectional, community-based study. Vet Rec 168:354.

63. Weese SJ (2008). Antimicrobial resistance in companion animals. Anim Health Res Rev 9(2):169-176.

64. Wiebe VJ, Howed JP (2009). Pharmacologic advances in canine and feline reproduction. Top Companion Anim Med 24(2):71-99. 